\title{
Development of Snakes and Ladders Game Media as Learning about Clean and Healthy Living Behavior At the Elementary School Level
}

\author{
M. Fajriannor TM ${ }^{1}$, Putri Vidiasari Darsono ${ }^{2}$ \\ \{fajriannor@unism.ac.id ${ }^{1}$, putrividiasari@unism.ac.id ${ }^{2}$ \} \\ Sari Mulia University, Banjarmasin, Indonesia \\ * fajriannor@unism.ac.id
}

\begin{abstract}
Globally, an estimated $40 \%$ of people live without basic sanitation. The existence of demographic and epidemiological transitions of the disease creates complex problems. mprovements cannot only be made to health services, the environment, or heredity, but also must emphasize the improvement of behavior that theoretically is proven to have a $30-35 \%$ contribution to the degree of health. This study aims to develop a snake ladder game media as a learning behavior of clean and healthy life at the elementary school level. This research is a research and development. The research was conducted at elementary school of Melayu Ulu, Martapura Timur District, Banjar Regency, South Kalimantan Province with the subjects being all fifth grade elementary school students totaling 19 people. The instruments used in this study were validation sheets and questionnaires. The data analysis technique used in this study is a quantitative descriptive analysis technique. The results of this study are in the form of a snake ladder game that gets media validation with a percentage of $87 \%$, material expert validation with a percentage of $91 \%$. The response results obtained that the response of teachers to the media is very good with an average percentage of $98.5 \%$ and student responses by $92 \%$. From the description, snake ladder game media is feasible and can be implemented for teaching and learning activities on clean and healthy living behavior materials.
\end{abstract}

Keywords: Hygiene; Media Development; Clean and Healthy Living Behavior; Sanitation; Snakes and Ladders Game

\section{Introduction}

Proper sanitation is a prerequisite needed to improve health standards and improve good quality of life. Globally, an estimated 40\% of people live without basic sanitation [1]. Data in 2013 showed that the percentage of the population with proper sanitation in South Kalimantan was at the lowest 3 levels compared to other provinces, which was only $35.14 \%$. The geographical condition of South Kalimantan, which is largely an area of water also plays a role in determining the percentage of households according to access to proper disposal of feces, where the national average is $55.5 \%$, while South Kalimantan is still at 50.9\% [2]. 
Banjar Regency is one of the regencies with geographical conditions that are mostly rivers. The existence of floating latrines on the river is still a chore for the government. Various attempts have been made to change the behavior of open defecation, especially in rivers into healthy latrines [3]. The incidence of diarrhea in Banjar District until 2016 is still very high when compared to other districts in South Kalimantan, namely as many as 9,920 cases. An increase in cases, in the last 3 years as many as 1,711 cases. In 2015 there were 8,209 , in 2016 there were 9,650 cases. One of the public health center that has the highest diarrhea cases and shows an increase in cases is Dalam Pagar Public Health Center. In 2013 there were 520 cases, in 2014 there were 919 cases, and in 2015 there were 1,141 cases. Cases of diarrhea from January to October 2016 in this public health center have reached 879 cases, with $76 \%$ of patients with diarrhea in the Dalam Pagar public health center area being male [3].

The results of Fajriannor's research (2016) state that the importance of health education in primary school age children is in terms of sanitation [4]. Schools play an important role in education because of its enormous influence on children's souls. Clean and healthy living behavior in schools is an effort to empower students, teachers, and the school community to know, want, and be able to practice Clean and healthy living behavior and play an active role in creating healthy schools [5]. Learning success is characterized by the acquisition of knowledge, skills, and positive attitudes in the individual. The success of this learning is greatly influenced by many factors, one of which is the use of instructional media that functions as an intermediary, container, or connecting learning messages. Learning media functions to direct students to obtain a variety of learning experiences. The teaching media is very helpful for teachers in providing maximum, effective, and efficient teaching [6]. Based on the description above, it is necessary to conduct research for the development of snakes and ladders game media as learning about clean and healthy living behavior at the elementary school level.

\section{Methods}

This research is a research and development. Initial research results serve as a reference to produce a product, in the process of developing researchers continue to make observations from product design to the time of testing the product in the field (10). The results developed in this research development are snake ladder media games in clean and healthy living behavior learning at the elementary school level. The stages of development research used by researchers are as follows: 


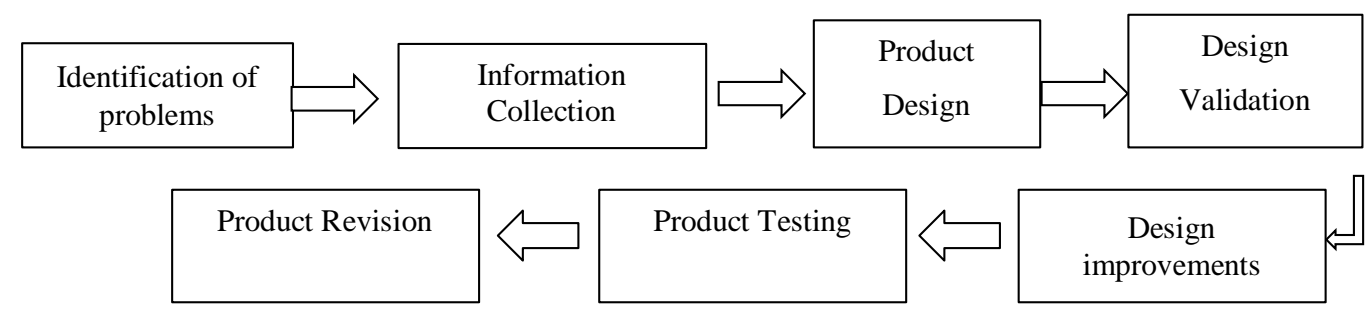

Figure 1. Stages of Development Research

The research was conducted at elementary school of Melayu Ulu, Martapura Timur District, Banjar Regency, South Kalimantan Province with the subjects being all fifth grade elementary school students totaling 19 people. The instruments used in this study were validation sheets and questionnaires. The data analysis technique used in this study is a quantitative descriptive analysis technique, namely by analyzing quantitative data obtained from the scoring scale of documentary studies conducted by researchers.

\section{Results}

\subsection{The process of making a snake ladder learning media game clean and healthy living behavior}

Descriptions of the design and draft of the product developed have specifications in the form of a snake ladder game in the learning of clean and healthy living behaviors for elementary school age children consisting of ladder snakes boards, pawns, and dice. Products in the form of game media snakes and ladders in learning clean and healthy living behavior is a modification of the original ladder snake game. The difference is that each plot presented in this snake and ladder game contains health messages related to clean and healthy living behaviors. The process of making game snakes and ladders is making images on the ladder snake board that is designed using a computer application. Snakes and ladders boards are made of A3 size art paper (AP), in which there are plots containing pictures of clean and healthy behavior. One dice as a calculation of the steps of the player / student, to run their respective pawns. Each side on the dice is listed numbers 1 to 6, how to use it is to throw it to the floor of the game. Pawn is used to represent the steps of the player / student in the game.

\subsection{The results of the feasibility of developing clean and healthy living behavior learning media}

\section{a. Media validation}

Based on the results of media validation, it is obtained that the media assessed in terms of the display aspect consists of 10 indicators, the programming aspect which consists of 9 indicators and the content aspect which consists of 13 indicators get an average percentage of 
$87 \%$ is categorized as "good" and must be partially revised in media that has already been developed. Suggestions obtained in the points of improvement are writing health messages that must be kept short and layout of images that must be considered. These improvements have been made to further enhance the learning madia and are appropriate for use.

\section{b. Material expert validation}

Material expert validation was conducted to obtain data on content and learning aspects consisting of 15 indicators, the results of the study showed that the percentage obtained from material experts was $91 \%$ classified as "Very Good" and slightly revised. The results of the assessment, input and advice provided by media experts / experts with material experts on the development of snakes and ladders games are the placement of images that must be tidied up and the use of color combinations to make them more beautiful.

\subsection{The teacher's response to the snake and ladder game media}

Based on the results of the responses obtained from the teacher's assessment it is known that the teacher's response to the media is very good with an average percentage of 98.5\% for all aspects of assessment. The evaluation aspects have each indicator for each aspect, namely:

\section{a. Learning aspects}

The assessment of this aspect aims to see the media developed in accordance with the indicators that are in it such as: (the suitability of the material with PHBS indicators at the elementary school level, the compatibility of the material with the objectives, the interactivity of students with the media). The percentage obtained from the assessment of teacher responses to the learning aspects is $100 \%$ and classified as very interested.

\section{b. Content / material aspects}

The assessment of the content / material aspects aims to see whether the media developed is in accordance with the material provided by the teacher to students in schools related to clean and healthy behavior. The percentage obtained from evaluating teacher responses to user aspects is $94 \%$ and is classified as very interested.

\section{c. User Aspect}

The assessment of this user aspect aims to find out whether this media can be used by the teacher in the ongoing learning process. This learning aspect consists of four indicators, namely: (ease of management, ease of use, clarity of media instructions and variations of playing instruments. Percentage obtained from evaluating teacher responses to user aspects is $100 \%$ and classified as very interested. 


\section{d. The aspects of the benefits of the game media snakes and ladders for teachers}

This aspect aims to find out the benefits of snake ladder game media for teachers in the learning process, this aspect consists of 5 indicators, namely: snake ladder game media can streamline the time in teaching clean and healthy living behavior, snake ladder game games can motivate students in learning, game media snakes and ladders can be used to increase learning more interesting and fun, media games snakes and ladders can be used to increase creativity in learning, and media games snakes and ladders can be used as a source learning for teachers and students in matters of clean and healthy living behavior.The percentage obtained from the teacher's response to the aspects of the benefits of snakes and ladder games is $100 \%$ and is classified as very interested.

\subsection{Student responses to snake ladder media}

Student responses to the snake ladder game media were given to students in class V / 5 totaling 19 students, from the total statements of students can be summarized in the following Table 1:

Table 1. Student responses to snake ladder media

\begin{tabular}{clcc}
\hline No. & \multicolumn{1}{c}{ Item Statement } & Percentage & Category \\
\hline 1 & $\begin{array}{l}\text { Student responses state learning with using } \\
\text { media is more fun than just using the } \\
\text { lecture method }\end{array}$ & 86 & Interested \\
\hline 2 & $\begin{array}{l}\text { Student responses state I feel fast bored } \\
\text { when taking "learning that just take notes } \\
\text { and listen to anything without any direct } \\
\text { interaction " }\end{array}$ & 83 & Interested \\
\hline 3 & $\begin{array}{l}\text { Student responses state I prefer interactive } \\
\text { teaching and learning process because more } \\
\text { quickly understand the subject matter. }\end{array}$ & 98 & Very interested \\
\hline 4 & $\begin{array}{l}\text { Student responses expressed that I felt } \\
\text { happy participating in learning activities } \\
\text { with the snakes and ladders game as a } \\
\text { learning media for clean and healthy living } \\
\text { behavior. }\end{array}$ & 93 & Very interested \\
\hline 5 & $\begin{array}{l}\text { The students' response stated that through } \\
\text { the game media Snakes and ladders made } \\
\text { me prefer health lessons, especially } \\
\text { material about clean and healthy living } \\
\text { behavior. }\end{array}$ & 91 & Very interested \\
\hline 6 & $\begin{array}{l}\text { Student responses stated that clean and } \\
\text { healthy living behavior material presented }\end{array}$ & 91 & Very interested \\
\hline
\end{tabular}




\begin{tabular}{|c|c|c|c|}
\hline & $\begin{array}{l}\text { with snakes and ladders game media was } \\
\text { easier to understand }\end{array}$ & & \\
\hline 7 & $\begin{array}{l}\text { Student responses state images that are } \\
\text { displayed on snakes and ladders game } \\
\text { media, made me better understand the clean } \\
\text { and healthy living behavior material. }\end{array}$ & 92 & Very interested \\
\hline 8 & $\begin{array}{l}\text { Student responses stated health messages } \\
\text { on the Snake ladder media game were easy } \\
\text { to understand. }\end{array}$ & 92 & Very interested \\
\hline 9 & $\begin{array}{l}\text { Student responses state pictures and } \\
\text { neatness the design is in the snake ladder } \\
\text { media game makes me more interested in } \\
\text { learning. }\end{array}$ & 95 & Very interested \\
\hline 10 & $\begin{array}{l}\text { Student responses state the material } \\
\text { presented in the game media snakes and } \\
\text { ladders can be repeated at any time thereby } \\
\text { increasing memory. }\end{array}$ & 93 & Very interested \\
\hline 11 & $\begin{array}{l}\text { Student responses state the color selection } \\
\text { at } \\
\text { media display game snakes and ladders is } \\
\text { good. }\end{array}$ & 95 & Very interested \\
\hline 12 & $\begin{array}{l}\text { Student responses state this media can } \\
\text { played at leisure. }\end{array}$ & 96 & Very interested \\
\hline 13 & $\begin{array}{l}\text { Student responses stated that snake ladder } \\
\text { game media is suitable for clean and } \\
\text { healthy living behavior material and other } \\
\text { health topics. }\end{array}$ & 91 & Very interested \\
\hline 14 & $\begin{array}{l}\text { Student responses expressed motivated to } \\
\text { Learn clean and healthy living behavior } \\
\text { with Snake ladder game learning media. }\end{array}$ & 91 & Very interested \\
\hline 15 & $\begin{array}{l}\text { Student responses state learning media } \\
\text { Snakes and ladders game is easy to } \\
\text { understand because of the explanation of } \\
\text { the game, the steps of the game and the } \\
\text { purpose of the game. }\end{array}$ & 93 & Very interested \\
\hline & Average total percentage & 92 & Very interested \\
\hline
\end{tabular}

Based on the overall percentage of students in Table 1 shows that from each statement from students categorized very well to the statement for each aspect that was responded to, with an average percentage of $92 \%$ and classified as very interested. 


\section{Conclusions}

Based on the results of the study found that the product in the form of a game media snakes and ladders in learning clean and healthy living behavior is a modification of the original ladder snake game. The difference is that each plot presented in this snake and ladder game contains health messages related to clean and healthy living behaviors. Based on the results of media validation, it is obtained that the media get an average percentage of $87 \%$, this is categorized as "good". The results of the validation of the material experts showed that the percentage obtained from the material experts was $91 \%$ classified as "Very Good". Based on the results of the responses found that the teacher's response to the media is very good with an average percentage of $98.5 \%$ and student responses of $92 \%$.

\section{Acknowledgements}

Thank you to the Ministry of Research, Technology and High Education for providing support in conducting research and the Head of Melayu Primary School in Martapura who has facilitated the research site.

\section{References}

[1] Okechukwu. Toilet Pratices Among The Inhabitants of Kintampo District of Northern Ghana. Journal of Medicine and Medical Sciences, 2012. 3(8): 522-530.

[2] Kementrian Kesehatan RI. Laporan Ringkasan Eksekutif Kalimantan Selatan Tahun 2013. Jakarta: Pusat Data dan Informasi Kementrian Kesehatan RI. 2013.

[3] Dinas Kesehatan Kabupaten Banjar. Profil Dinas Kesehatan Kabupaten Banjar Tahun 2016. Martapura: Dinas Kesehatan Kabupaten Banjar. 2016.

[4] Fajriannor M, Shaluhiyah Z, Nugraha P. Pengaruh Pendidikan Kesehatan Pada Orang Tua Melalui Anak Terhadap Pengetahuan, Sikap, Dan Praktek Penggunaan Jamban Sehat Di Wilayah Kerja Puskesmas Dalam Pagar. Semarang: Magister Promosi Kesehatan Universitas Diponegoro.

[5] Widoyono. Penyakit Tropis: Epidemiologi, Penularan, Pencegahan, dan Pemberantasannya. Semarang: Erlangga. 2008.

[6] Irwan D. Pengembangan Media Permainan (Game) Monopoli Pada Pembelajaran Fisika Materi Besaran Dan Satuan Pada Tingkat Sekolah Menengah Pertama (SMP). [Skripsi]. Banda Aceh: Universitas Islam Negeri Ar-Raniry Darussalam. 2017.

[7] Elisabeth T. Faktor - Faktor yang Mempengaruhi Partisipasi Keluarga dalam Penggunaan Jamban di Kota Kabanjahe Tahun 2007. [Tesis]. Medan: Universitas Sumatera Utara. 2008.

[8] Notoatmodjo S. Pendidikan dan Perilaku Kesehatan. Jakarta: Penerbit Rineka Cipta. 2012.

[9] Kurniawati D, Rohmana DY, Juliningrum PP. Pengaruh Permainan Ular Tangga terhadap Pengetahuan dan Sikap dalam Menghadapi Menarche pada Siswi SDN Pringgowirawan Sumberbaru Kabupaten Jember. e-Jurnal Pustaka Kesehatan 2017. 5(1): 71-76.

[10] Sugiyono. Metode Penelitian Kuantitatif Kualitatif R\&D. Bandung: Alfabeta. 2002. 
[11] Gede Martha Adi Pariartha, dkk. Pengembangan Media Pembelajaran Berbasis Multimedia Interaktif pada Mata Pelajaran IPA untuk Siswa Kelas VIII Semester 1 di SMP Negeri 3 Singaraja Tahun Pelajaran 2012. Denpasar: Universitas Pendidikan Ganesha Jurusan Teknologi Pendidikan. 2013.

[12] Isni Wardaton. Pengembangan Media Pembelajaran Berbasis Animasi Komputer pada Pokok Bahasan Listrik Dinamis (Studi Eksperimen di Kelas X Darul Ihsan Aceh Besar). [Skripsi]. Banda Aceh: Fakultas Tarbiyah dan Keguruan UIN AR-Raniry. 2013. 